\title{
A methodical approach to the assessment of human resources interactions
}

\section{Anna Pereverzieva ${ }^{1}$}

\begin{abstract}
To our knowledge, there is a need to develop a methodological approach to the assessment of united communities ' human resources 'level of interactions, as a large group, and of separate structural unit's - a small group. This allows us to determine the dependence of the level of interactions on the number of people who interact within a particular structure and the nature of the activity they carry out - intellectual or manual labor. The purpose of our research is to develop a methodological approach to the assessment of the level of human resources 'interactions, which allows us to identify key areas and policy measures. Expert assessments and analytical dependencies are used as research tools in the article. These tools allow us to quantitatively determine the level of human resources 'interactions for an individual entity. Empirical implementation of the proposed approach, using the example of two entities varying in size and nature of labor, allowed us to make a comparative analysis and to distinguish the characteristic features that are the basis for making managerial decisions. A manager acts as an expert who assesses the presence or absence of a particular event in the subordinate unit. The indicator, which characterizes the presence or absence of certain activities and the level of participation in them, is defined on the basis of managerial assessment. The next stage is to determine the interaction rate by means of certain mathematical dependencies and results 'analysis. As a result of the research, we got the assessment of the level of human resources 'interactions between two entities - a united community and a structural unit. The assessment revealed a dependence on the level of interactions on the entity's size (small and large groups) and the nature of labor. The results showed that a structural unit, focused on intellectual labor and presented by a small group, has a greater level of interactions than a united community, which has a bigger size and a predominance of manual labor.
\end{abstract}

Keywords: assessment, human resources, interactions, labor, synergistic effect.

1 Anna Pereverzieva, Associate Professor of international economy, natural resources and economic theory department, at Zaporizhzhya National University, Kronschtadtska str., 2a, 22, 69001, Zaporizhzhya, Ukraine, e-mail: pereverzeva@ukr.net (ORCID ID: 0000-0001-8391-6636).

Received 4 April 2018; Revised 16 August 2018, 9 November 2018, 10 February 2019; Accepted 22 February 2019 


\section{INTRODUCTION}

At the present stage of society's development, there is a dynamic increase in the significance of human resources for the economy as a whole, and for individual business entities in particular. This happens due to the impact of the level of knowledge and individual qualities aimed at obtaining a high level of performance. These are people who are perceived as the "element" that can create value, and only they can force the equipment to operate at the expense of their intellectual potential. Each person is characterized by certain abilities that give the possibility to perform the imposed functions and to participate in certain activities. The peculiarity in the process of maximal realization of human potential is that the individual abilities of a person can only be detected in the process of interactions with others - latent abilities. Only under these conditions will the available knowledge and abilities bring the expected result concerning individual development and business entity's success. This is also important for a manager since an efficient and united team envisages not only the automatic distribution of roles and labor functions but also the availability of interaction, collaboration, support and assistance on the way to the common goal. Knowledge accumulation is also the result of interactions, which manifests itself in the ability to benefit from the knowledge of other team members. However, one should not forget that team interactions might have a mixed impact on the activities' results, and can both increase and reduce them, for example, because of a conflict situation. Therefore, an important task for a manager is to ensure a high level of teamwork, as well as its support and development in the future.

The functioning of a particular team or group should be regarded as a certain system, all the elements of which are interrelated, and can either strengthen or weaken each other. According to a systemic approach, the issue of co-existence and interactions between people within a particular system becomes of particular importance, because the quality of these interactions depends on the success of the system 's functioning and its future development. Any system has a certain set of elements that interact with each other. The result of these interactions is achieved on the basis of aggregate potential use, rather than the potential capabilities of its elements. On this basis, it can be stated that the whole is greater than simply the sum of its constituent elements. At the same time, the category "whole" refers to the system in general (an enterprise, a united territorial community), and "parts" are individuals and human resources. These words certify the fact that it is impossible to provide a high level of an enterprise 's operation efficiency and to create a productive united territorial community without achieving a high level of interactions between human resources who act as a driving force. 
Achievement of a certain synergetic effect is the consequence of interactions between system parts. It shows the nature and strength of interactions between a system's parts, for example, between human resources within united territorial communities. The synergetic effect is reflected in both positive and negative results, i.e., it characterizes the direction of interactions. The strength of interactions directly influences the system 's development; that is, the stronger its elements are connected through the possibilities of co-existence; the greater the probability of successful development is.

In this study, united territorial communities and a structural unit (university department) are considered as systems. In this case, a community is an example of a large group with a predominance of manual labor, and a structural unit is an example of a small group with domination of intellectual labor. Let us substantiate the need to take into account the level of human resources' interactions for communities.

The formation of united territorial communities means the implementation of a national decentralization policy aimed at increasing the efficiency of a national economy's functioning and raising the living standard of the population by redistributing powers and financial resources and involving citizens in management. Herewith, the issue is the formation of efficient territorial communities whose functioning depends to a large extent on resource provision, among which the key role belongs to human resources: not only to determine the real possibilities of a territorial community which can meet its own needs but also to form potential opportunities for future development. Any territorial community at the beginning of its formation faces a significant number of obstacles, directly related to human resources. The most important are the deficit of human resources with relevant qualifications, low levels of motivation, a lack of substantial participation in a community's life, and other issues that require optimal solutions. These problems cause the necessity to study and evaluate the level of interactions between a community`s human and labor resources.

A positive synergetic effect should be achieved inside united territorial communities, as it affects the community's ability to accomplish common goals. After all, as economic facts show, communities are formed on the basis of certain criteria defined by law, that is, there is a significant level of conventionality regarding their formation. Therefore, for the united territorial communities, it is important to achieve only a positive synergistic effect that will allow them to evolve in the future. If a negative impact of synergy is detected, it is necessary to provide the tools to increase the impact of human resources interactions within the community. Tools' development, aimed at enhancing the interactions between human resources, is an integral 
part of the process of a socio-economic system `s management, i.e. a united territorial community.

The analysis of the level of a structural unit's (university department) human resources' interactions is of a small group with a domination of intellectual labor. This lets us determine whether there is a correlation between the level of human resources' interactions and the group size and its type - either direct or inverse, as well as a correlation between the levels of interactions in teams engaged in manual or intellectual labor, that is, differences caused by the nature of labor. Teams characterized by intellectual labor have considerable intellectual potential and, as a rule, it is difficult for them to find a common point of view because of the unwillingness of some team members to meet halfway, or to walk a thin line, to take consensus. However, if there is a high level of interactions, the process of finding a common point in the team of "intellectuals" is successful. This directly affects the activities` outcomes both of a separate unit (element of system), and an organization in general (system).

The level of interactions affects activity outcomes and supposes the application of measures for their future adjustment based on the human resources management policy by increasing the level of interactions between them. The development of measures to enhance human resources' interactions is an integral part of the process of socio-economic systems' management, namely a united territorial community and a structural unit. The methodical approach proposed in the study allows us not only to quantify the level of interactions on the basis of the coefficient's calculation, but to identify the "weaknesses" that reduce the strength of interactions and "strong points", which are the background for the successful co-existence of a community's and structural unit's human resources.

The aim of this study is to determine the methodological approach to the assessment of human resources interactions. This approach is universal, as it can be used for various economic actors both at macro- and micro-levels - enterprises, united territorial communities and others. The peculiarity of using this approach with united territorial communities is to achieve a high level of interactions not by the number of community members, but by the intensification level of their participation in joint activities and projects. That is, a high level of interactions can be achieved in big groups too. It depends on the effectiveness of human resources management methods in the community and the level of self-organization. Comparative analysis with the level of human resources 'interactions within a structural unit allows us to state the fact of its dependence on the team size - a small group or a large one. Besides, the nature of labor - intellectual or manual was considered as 
the determinant affecting the level of interactions. To carry out the research and justify the obtained results, we will consider several hypotheses.

We propose the following hypotheses for testing:

$\mathrm{H} 1$ : There is a relationship between the level of human resources interactions and the group size (co-workers, association of people), the nature of which may be determined by the ability to self-organization and management system`s features.

$\mathrm{H} 2$ : The level of team interactions based on intellectual nature of labor, which is determined by the more active participation of human resources in group's activities, than in associations with the predominance of manual labor.

H3: the level of interactions affects the results of the entity's business due to the positive effects of synergy

\section{LITERATURE REVIEW}

Amid increasing instability of economic development, raising the level of economic entities 'efficiency is a matter of current interest as their functioning depends to a large extent on resource provision, among which the key role belongs to human resources, which not only determine the real possibilities of functioning but also form potential opportunities for their future development. In particular, the true capabilities of a business entity can be determined by quantitative indicators, but potential can be determined by a human resources' interactions' rate, which is one of the priorities of an entity's effective development and operation. "Interactions" are considered from a theoretical point of view within the framework of interdisciplinary analysis by scientific literature (Figure 1). Practical elements of interactions are investigated by scholars in terms of their impact on the business entity's performance (productivity, creation and implementation of innovations). Besides, on the basis of factors analysis they affect the strength of interactions between people (presence of a certain team leader, the psychological need of a person to be "included" in a certain group, the involvement of temporary workers, the appearance of "stars" in a team, staff turnover, doing "standard" tasks, etc.). 


\section{Study of the theoretical aspects of the "interactions" category}

The concept of "interactions" arises and causes considerable interest among scholars within the framework of a modern paradigm - Synergetics, which examines complex systems that consist of a large number of components or subsystems, in other words, details interacting with each other in complex ways. The word "synergetics" means "joint action," emphasizing the coherence of the parts' functioning, which is reflected in the behavior of the system as a whole (Melnikov, 2014).

In the functioning of business entities, scientists single out the following types of synergies: structural, functional and administrative:

- structural synergy originates from the organization's structure, and depends on the available information flows, the intergroup relationships and their positioning relative to each other. The main condition for structural synergy development is the presence of a culture in which group behavior rules take into account the individual needs of team members, systematic conflict situations prevention is implemented, there is an openness to group work, and there is a clear understanding of the value of teamwork to achieve the overall final result;

- functional synergy is balanced interactions of team human resources based on common goals, consonance of interests, and the introduction of innovations;

- administrative synergy determines the external impact on a group or team.

The concept of "interactions" is the object of research within the framework of interdisciplinary analysis. Each of the fields of science provides its own definition of this category (Figure 1).

The definitions 'analysis in the context of separate fields of knowledge shows that the common understanding for all interpretations is the explanation of "interactions" through the way of mutual influence, liaise and unity, which makes it possible to achieve results with fewer resources than the efforts required to attain a goal individually. We analyze the definition of "interactions" according to the approach to categories structure proposed by Starostina (2011). This approach implies that the constituent elements in a category's construction should be "essence," " structure " and "result." The element "essence" answers the question "what?", "structure" - "how? whence?", and "result" - "for which reason?". Table 1 represents the construction of the category "interactions" in terms of the proposed approach. 


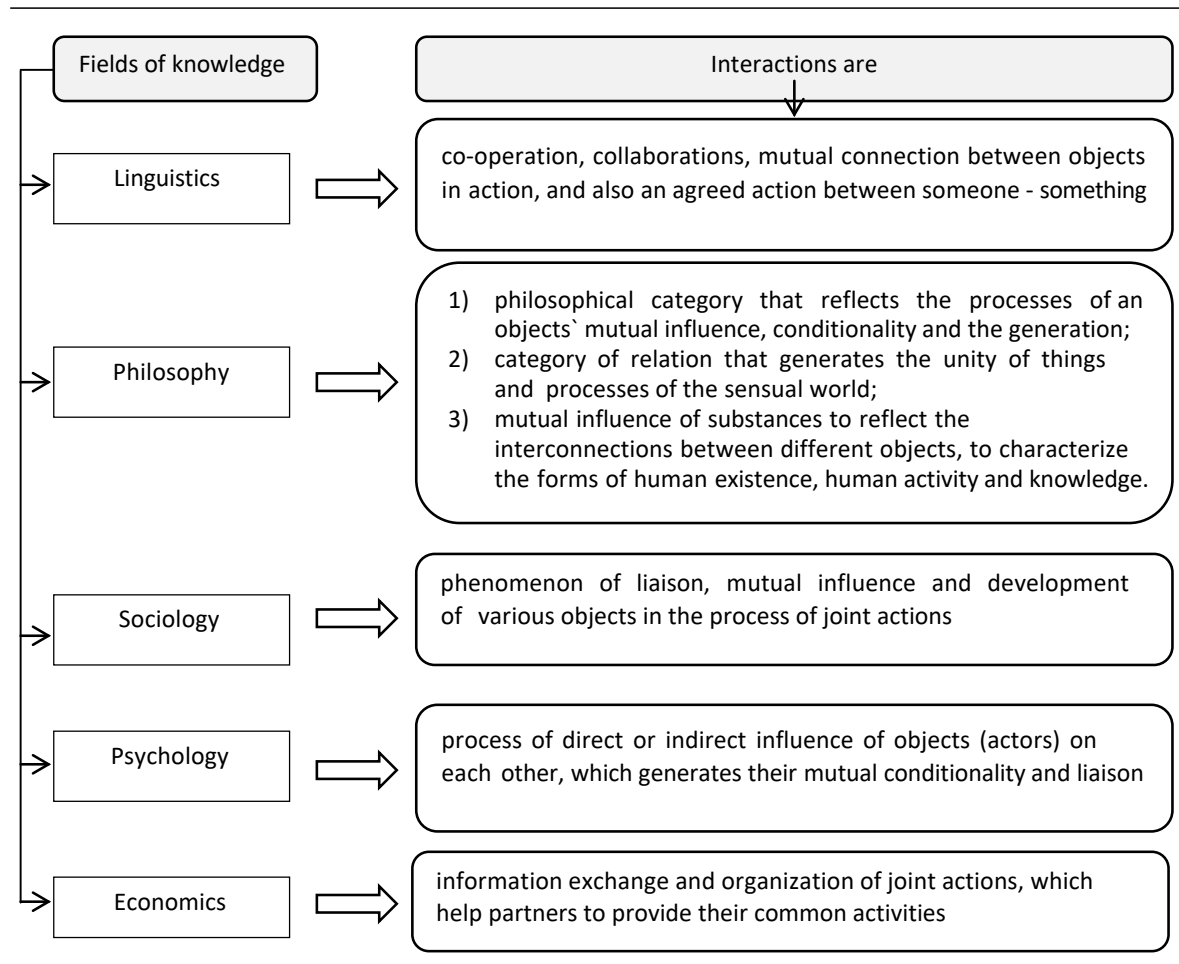

Figure 1. Definition of the category "interactions"

Source: adopted from Gonchar (2008), Morozov (2015) and Gornostai (2015).

Most of "interactions" definitions are incomplete, as they contain two of the three necessary elements regarding the approach to categories construction. When studying the essence of the "interactions" category, it should be noted that from the Linguistics point of view, this category is defined as a mutual connection, while Philosophy defines it as the impact of one object on another. The definition of "interactions" from the Sociology and Psychology points of view combines both relations and influence simultaneously. Economics defines interactions as a process of organizing joint actions that allow us to reach a certain result. While there is considerable interest in such a concept as "interactions" within various disciplines, it indicates the existence of this phenomenon and its importance in various spheres of human activity. Because a person is a part of a particular environment, the question of interactions with others to maximize selfrealization and achieve a collective success arises. 
Table 1. Construction of the category «interactions»

\begin{tabular}{|c|c|c|c|}
\hline Field of knowledge & «essence» & "structure» & "result» \\
\hline Column 1 & Column 2 & Column 3 & Column 4 \\
\hline Linguistics & $\begin{array}{l}\text { co-operation } \\
\text { collaboration }\end{array}$ & $\begin{array}{l}\text { mutual connections } \\
\text { between objects } \\
\text { in action, and also } \\
\text { an agreed action } \\
\text { between someone - } \\
\text { something }\end{array}$ & - \\
\hline \multirow[t]{3}{*}{ Philosophy } & philosophical category & $\begin{array}{l}\text { reflects the } \\
\text { processes of objects' } \\
\text { mutual influence, } \\
\text { conditionality and } \\
\text { the generation }\end{array}$ & - \\
\hline & category of relation & $\begin{array}{l}\text { that generates the } \\
\text { unity of things and } \\
\text { processes of the } \\
\text { sensual world }\end{array}$ & - \\
\hline & $\begin{array}{l}\text { mutual influence of } \\
\text { substances }\end{array}$ & - & $\begin{array}{l}\text { to reflect the } \\
\text { interconnections } \\
\text { between different } \\
\text { objects, to characterize } \\
\text { the forms of human } \\
\text { existence, human } \\
\text { activity and knowledge }\end{array}$ \\
\hline Sociology & $\begin{array}{l}\text { phenomenon of liaison, } \\
\text { mutual influence and } \\
\text { development of various } \\
\text { objects }\end{array}$ & $\begin{array}{l}\text { in the process of } \\
\text { joint actions }\end{array}$ & - \\
\hline Psychology & $\begin{array}{l}\text { the process of direct } \\
\text { or indirect influence of } \\
\text { objects (actors) on each } \\
\text { other }\end{array}$ & $\begin{array}{l}\text { which generates } \\
\text { their mutual } \\
\text { conditionality and } \\
\text { liaison }\end{array}$ & - \\
\hline Economics & $\begin{array}{l}\text { information exchange } \\
\text { and joint activities } \\
\text { arrangement }\end{array}$ & & $\begin{array}{l}\text { helps partners to } \\
\text { implement some joint } \\
\text { activity }\end{array}$ \\
\hline
\end{tabular}

\section{Contemporary empirical studies of human resources`interactions}

In addition to the definition of theoretical foundations of interpersonal interactions, an important role is played by modern empirical research. In scholars "studies, the concept of "interactions" is considered from the point of view of the determinants that influence the formation of a human-coexistence environment, their relationships with each other and the outcomes. One of 
the most important determinants 'influencing human resources 'interactions within a certain system (enterprise, its structural unit, etc.) is the existence of a leader in a particular group. Studies reveal the impact of a leader's personal psychological qualities on a team's functioning and development (Liborius, 2017) and his/her role in ensuring conducive working conditions (Brimhall et al., 2017). Qualities also include age, education, and other individual leader's characteristics (Kearney \& Gebert, 2009). Scientists emphasize that the creativity of a leader can be channeled on team characteristics (Gibson, Cooper, \& Conger, 2009; Tse, To, \& Chiu, 2018). At the same time, the role of the leader in increasing the level of interactions can be both positive and negative. Studies by Lopez (2018) show a negative leadership influence on employees' interactions. This is explained by its advantage in managing time distribution, determining improvement trends, and not taking into account the opinion of others. Three types of leadership are distinguished: moral, benevolent and authoritarian (Lin \& Sun, 2018). Studies showed that moral leadership has the greatest impact on interactions, and authoritarian has the least. In our opinion, this confirms the change in an individual's role, his/ her values and social attitudes. This causes the necessity to formulate the concept of human resources management based on the increased level and strength of interactions. In this regard, the question of an individual's increasing significance arises, giving him/her the "voice," which facilitates the intensification of information exchange and, accordingly, inter-person and inter-leader interactions (Cumberland, Alagaraja, Shuck, \& Kerrick, 2018). Besides, scholars note that it is necessary to differentiate situations that require "voice" or "silence," as well as to understand the possible consequences (Morrison, 2011).

Hirst and van Dick (2009) proved the serious influence a leader's motivation has on teamwork, creativity and creative work. The researchers also identified a direct dependence between a leader's motivation and team creativity based on his/her trustworthiness among others. An important role is played by inter-group leadership, which promotes not only interactions and productivity within a group of people but also within other teams (Hogg \& van Knippenberg, 2012).

Social psychology considers interactions between people as a need for "inclusion" in a particular group and differentiation in it (Leonardelli, Pickett, \& Brewer, 2010). The sense of belonging to a particular team increases work efficiency (Mitchell, Parker, \& Giles, 2011). It reduces the level of antagonism and increases the chances of conflict solving (Somech, Desivilya, \& Lidogoster, 2009). Interactions can also be affected by the so-called "psychological contract" in a team, that is, clearly defined principles of establishing team relationships (Bingham, Oldroyd, Thompson, Bednar, \& Bunderson, 2014). 
Studying interactions between executives (managers) and employees, scientists have proved that the greater the quality of interactions between executives and employees, the higher the quality and work productivity of the latter (Zanozovska, 2017). There are interesting research studies on the impact of executives' managerial humor on teamwork (Wijewardena, Härtel, \& Samaratunge, 2017). Humour is an event run by managers in order to provoke a positive emotional reaction from employees and create an appropriately favorable working environment. It was confirmed that a noticeable level of interactions with a manager engenders a positive staff response to humor, and vice versa. In addition, a manager's behavior and support that helps form the staff's attitude to work also play a substantial role (Teoh, Coyne, Devonish, Leather, \& Zarola, 2017). In turn, this contributes to greater team interactions and increases the level of job satisfaction. Russell et al. (2018) also considered the key role of a manager in the regulation of inter-person relationships. Within the dynamic management theory, the influence of managerial abilities on human interactions and the ability to regulate it, taking into account the dynamism of the environment and the need to respond promptly to changes, is considered (Martin, 2011; Helfat \& Martin, 2015; Helfat \& Peteraf, 2015).

Examining the role of inter-person interactions, scholars determine that the higher the level of interactions in a team, the less the impact is on human behavior and the results of stress caused by work overload and interpersonal conflict (Pooja, De Clercq, \& Belausteguigoitia, 2016). Positive influence also manifests itself in the level of employees 'complementarity (Ethiraj \& Garg, 2012). In such cases, three aspects determine the level of complementarity: the nature of interactions, the dominance of team members and its structure. Scholars proved that the higher the level of interperson interactions, the more team members focused on teamwork, the higher the level of complementarity is. If certain team members are on the front foot, this leads to a decrease in the level of complementarity. This is ensured by the dynamism of the team, in which members can easily move within and outside their group (Dibble \& Gibson, 2018; Faraj \& Yan, 2009).

Labor motivation is important for human resources management (Glaz \& Rusetskaya, 2017; Keizer, 2017; Bridoux, Coeurderoy, \& Durand, 2017). Scholars, investigating the influence of internal and external motives, concluded that interactions as the internal motive promote the intensification of innovation activity by high rates of progress. Adequate remuneration, which also contributes to the creation of innovations through the mitigation of the negative impact of labor intensity, is figured to be among the external motives (Delmas \& Pekovic, 2018). Analyzing the impact of employees` interactions, which is manifested in knowledge sharing and job satisfaction, a group of 
researchers demonstrated an increase in the level of innovativeness in the service sector (Okoe \& Boateng, 2018).

To implement the innovation activity, a team should create an idea and implement it. Research shows that the levels of interactions at these two stages are different: the creation of an idea is characterized by the lower level of interactions due to traditional methods, and implementation is characterized by high interactions of people, as it involves the application of new creative approaches (Huang, Gibson, Kirkman, \& Shapiro, 2017). Somech and Khalaili (2014) studied a group's ability to innovate activity based on its structure and reflexivity (Schippers, West, \& Dawson, 2015). Salvato and Vassolo (2018) emphasized the leading role of human resources in the organization's activities and interactions between them in their scientific works. Scientists confirmed that the ability to use interactions makes it possible to build highquality organizational relationships. This greatly enhances its innovative potential in a dynamic environment and improves operational efficiency. This gives priority to the need for interactions not only within one group of people but cooperation between groups - intergroup interactions (Litchfield et al., 2018). Based on empirical research, Hülsheger, Anderson and Salgado (2009) found a direct correlation between team creativity and innovation activity. The obtained results showed that the level of team creativity is higher than individual creativity; thus a team's ability to create and introduce innovations increases. Kostopoulos et al. (2009) explain the benefits of interactions and teamwork based on the fact that the effectiveness of team learning and its impact on efficiency is higher than in the case of individual training. Also, it was found that teamwork and reciprocity have a positive impact on productivity (Mortensen, 2014). The results of Huckman, Staats and Upton (2009) demonstrated that the intensity of human interactions, for example, the execution of joint projects, has a much greater effect on performance than other determinants such as existing work experience.

Scholars specify hiring temporary workers to teamwork as one of the methods of increasing the level of interactions and its strength (Tempest, 2009; Wilkin, de Jong, \& Rubino, 2018). At the same time, the impact analysis of this type of worker on the main team structure proves the lack of fundamental changes in the efficiency of group as a whole (Banerjee, Tolbert, \& DiCiccio, 2012). The impact of "standardized" tasks on the level of intergroup interactions was determined as scientifically valid and empirically proved (Rousseau \& Aubé, 2010; Cohen, Levinthal, \& Warglien, 2014). The more standard the task, the higher are the viability of a team and its effectiveness. In our opinion, this pattern depends on a team's peculiarities, because, as a rule, the very "non-standard" creative tasks contribute to the efficiency of teamwork and increase the strength of interactions. Scholars admit when 
determining the impact of teamwork on a company's performance that it is necessary to take into account its industry specificity and the nature of the labor (Gaisina et al., 2017), as well as a team's heterogeneity or similarity, i.e. the group's structure (Drach-Zahavy \& Somech, 2010; Bell, Villado, Lukasik, Belau, \& Briggs, 2011). Faraj and Yan (2009) studied, from the point of view of psychological interactions, the possibility of coexistence within a team, whilst others found that changes in group structure affect the level of interactions between its members, and their performance in general (Fang, Lee, \& Schilling, 2010).

Analyzing the peculiarities of a human resources management policy that form a particular team, scholars point out that effective management is determined by the ability to work in a team and interact with each other. This allows them to obtain new opportunities for both team development and the enterprise as a whole (Edmondson \& Nembhard, 2009; Gibson \& Dibble, 2013). The important attribute is the sustainability of team members' interactions. In addition, it should be taken into consideration that accepting a "freshman" into a team may have an ambivalent impact on interactions. Therefore, the problem of team and individual adaptation arises (Rink, Kane, \& Ellemers, 2013). Considering the features of team interactions, scholars highlight such essential attributes as conscientiousness, emotional stability and the acceptability of relationships, and that these attributes of interactions are related to a company`s financial performance (Schneider \& Bartram, 2017).

The real obstacle to effective interactions between employees is the so-called team "star" (Chen \& Garg, 2018). The "Star" is an employee who differs from others by a significant level of success over a long period of time (Call \& Nyberg, 2015). In this case, the organization of teamwork and interactions is rather complicated. Scholars consider that the temporary suspension of a "star" from work for a certain time could be the solution to this issue. Studies showed that the absence of a "star" allows a team to reduce dependence on this employee and improve teamwork performance through interactions. Improvement in teamwork contributes to increased productivity, even if the "star" returns. In our opinion, "stars" as team members cause negative consequences in terms of interactions between people and may lead to the formation of separate groups, which ultimately reduces an enterprise's performance. On the other hand, the "star's" success may become a powerful motive to intensify the efforts of others. Grigoriou and Rothaermel (2014) distinguish two kinds of "stars": those that are able to unite people - "connectors" and, conversely, those who weaken interactions - "disconnectors". "Connectors" have a positive influence due to their ability to improve productivity around themselves. Another factor 
that negatively affects the level of team interactions is staff turnover (van der Vegt, Bunderson, \& Kuipers, 2010).

Analysis of the "interactions" theoretical and empirical aspects proves the necessity of taking this phenomenon into account in the activity of any business entity, as it is directly related to the relationships between people. Being aware of the level of human resources interactions allows us not only to state the presence or absence of coordination and essential connections but also to define the "portfolio" of management tools and measures that increase the strength of these interactions and obtain expected results in the future.

\section{RESEARCH METHODS}

It is difficult enough to assess quantitatively qualitative aspects related to human activity, which involves interactions between people. This is due to the peculiarities of each business entity's activity, which requires an individual approach to assessing the level of human resources' interactions. Therefore, in this manuscript, we propose the methodological approach to assessing the level of human resources' interactions for a community as a large group with manual labor domination and a structural unit (university department) as a small group with intellectual labor domination. Certainly, this approach can be used by other business entities and allows one to reveal the features of human resources' interactions, taking into account certain characteristics (size of a business entity, number of human resources, activity type, nature of labor, etc.). The assessment of a human resources' interactions level will be made using the example of a community and a structural unit. Let us consider consistently the determination of the interactions' level for each business entity. The main tool of the study is the method of expert assessment and application of certain mathematical dependencies to determine the coefficient of interactions, which involves the implementation of the system of actions:

- definition of activities, which exist in the community. Determined by an expert as a head;

- evaluation of human and labor resources' participation in certain events according to the introduced scale;

- calculation of the coefficient of a community`s human and labor resources interactions using mathematical dependencies;

- calculation of the adjusted interaction coefficient taking into account the number of participants in a particular activity on the basis of the proposed analytical toolkit.

Let us consider in more detail the sequence of estimation of the level of human and labor resources 'interactions of united territorial communities. We consider in detail the steps of the algorithm to assess the level of interactions 
between human and labor resources of united territorial communities. To quantify the level of human resources interactions within a united territorial community, it is possible to use the coefficient of interactions $\left(k_{j}\right)$, which has a synergetic effect for the functioning and development of a territorial community. The coefficient $\left(k_{j}\right)$ takes into account the level of community members 'interactions and simultaneously acts as a multiplier. The strength or quality of these interactions leads to a synergistic effect. That is, the total human potential of the entire territorial community is not just the sum of each community members' potential, but may either be increased (strengthened) through collaboration, or reduced (weakened), for example, by conflict situations.

The assessment of the coefficient could be made for human resources in general, that is people who are community members, and for a specific group of employees. We distinguish these two groups for a community, as employees tend to have limited time resources and are not inclined to participate in activities that unite people within a particular institute and facilitate their interactions. We offer a methodical approach to estimation of the coefficient of interactions, which takes into account the extent of community members' participation in its activities.

A list of $N$ activities in which community members may take part is determined $\left(k_{j}=\overline{1, M}\right)$, where $M$ - number of entities studied according to the coefficient of human resources' interactions. It characterizes the quality of community members' interactions. Participation in each activity will be evaluated using a scale:

The total coefficient of interactions is determined by the formula:

$$
k_{j}=1+\frac{\sum_{i=1}^{N} d_{i}}{N},
$$

where $d_{i}=\left\{\begin{array}{l}1, \text { there is a community activity in which community members } \\ \text { participate; } 0 \text {, do not participate; } \\ -1, \text { there are no activities in the community }\end{array}\right.$

The head of a community acts as an expert who assesses coefficient $d_{i}$. Information about community members 'participation in a particular event is recorded during its arrangement. This can be done by providing some attributes for the participants. To do this, you need to calculate the difference between the maximum number of required attributes and the amount of attributes provided to the participants. This allows one to determine the participants of the event. Besides, one can apply polling. It should be noted that attributes also contribute to the participant's self-identification 
as a united team member and the awareness of his/her importance in its functioning and development.

When determining the coefficient of interactions within united territorial communities, it is advisable to take into account the number of participants of a particular activity. As was mentioned above, what should also be taken into account is the participation of human resources in general and employees as well, considering their limited time and their passive participation in the activities.

The adjusted coefficient of interactions which includes the number of participants:

$$
k_{j}=1+\overline{Q_{H R_{l}}} \times \frac{\sum_{i=1}^{N} d_{i}}{N}
$$

where $\overline{Q_{H R}}-$ the geometric mean value of a united territorial community`s human resources'share, who participated in the activities

$$
\overline{Q_{H R_{l}}}=\sqrt[N]{\prod_{i=1}^{N} \frac{H R_{i}}{H R}},
$$

where $H R$ - total number of community members, persons;

$H R_{i}$ - number of community members, who partic-ipated in the activities, persons;

$N$ - number of activities, for which $d_{i}=1$.

Consider the calculation of the adjusted coefficient of interactions for labor resources. The adjusted coefficient of interactions considers the number of participants

$$
k_{j}=1+\overline{Q_{L R_{l}}} \times \frac{\sum_{i=1}^{N} d_{i}}{N}
$$

where $\overline{Q_{L R}}$ - the geometric mean value of a united territorial community`s working population share, who participated in the activities

$$
\overline{Q_{L R_{l}}}=\sqrt[N]{\prod_{i=1}^{N} \frac{L R_{i}}{H R}}
$$

where $H R$ - total number of community members, persons;

$L R_{i}$ - number of a community`s working population, who participated in the activities, persons;

$N$ - number of activities, for which $d_{i}=1$. 
To calculate mean values $\overline{Q_{H R_{i}}}$ and $\overline{Q_{L R_{i}}}$ we do not use an arithmetic mean, but a geometric mean formula. The geometric mean allows considering both high and low values of the indexes, whereas the arithmetic mean allows compensating low values by high ones. The last does not provide a fair assessment.

Taking into account geometric mean values $\overline{Q_{H R_{i}}}$ and $\overline{Q_{L R_{i}}}$ allow us to determine the number of people who took part in certain activities. We can assume that the more the number of participants in a particular event, the higher is the probability of interactions between them. It can happen through mutual communications during direct participation in the event or in the process of future communications - when meeting and recollecting participation in a particular event. This contributes not only to greater the level of interactions, but also increases the group members 'openness rate through mutual communications and maintaining contacts.

Increasing frequency of communication deepens the level of group members`awareness and raises the level of openness to each other. It should also be noted that if a person is open to a certain group, then the probability of increasing the level of openness to each member of this group is higher, due to the sense of belonging to a certain group. On the contrary, if a person is "closed" relative to a group, the probability of openness to a group member decreases. If a person is a potential participant of a particular group, then on the basis of openness to the group it can be stated whether he/she can become a full team member and develop successfully in it, or, on the contrary, there is an increase in the distance between a person and a team, the level of "closeness" increases, even if there is a significant level of openness with at least one member of this team. That is, it is the group's openness and interactions that determine its ability to attract new members and to succeed through the harmonious coexistence of human resources within a particular environment. Features of the work environment are determined by the dominance of human resources that are close to certain psychological characteristics, the similarity of characters, the type of temperament or socio-psychological orientations that manifest themselves in attitudes to work and money, the focus on activities or processes, altruism or selfishness, submissiveness or freedom. The level of human resources' interactions within a certain group with a significant degree of similarity of these characteristics is much higher. 


\section{ANALYSIS AND RESULTS}

To conduct comparative analysis and distinguish the features of interactions, we applied the proposed approach to two entities: a united territorial community as a large group, whose members are mainly involved in manual labor and a structural unit (university department), whose labor resources form a small group and do intellectual work. This makes it possible to distinguish two criteria for comparing the level of interactions: the group size and the nature of labor. The practical application of the proposed approach involves a procedure, that is, a certain action plan (Figure 2).

\begin{tabular}{|l|l|l|}
\hline STAGE 1 & $\begin{array}{l}\text { Information classification concerning the activity list and the number of } \\
\text { participants }\end{array}$ & \begin{tabular}{|l|l|}
\hline Determination of coefficient $d_{i}$ based on expert assessment (the \\
communities or department heads act as the experts)
\end{tabular} \\
\hline STAGE 3 & $\begin{array}{l}\text { Determination of the coefficient of interactions } k_{j} \text { for the community } \\
\text { members (large group with a manual nature of labor) and department } \\
\text { unit's team (small group with an intellectual nature of labor) }\end{array}$ \\
\hline STAGE 4 & $\begin{array}{l}\text { Determination of the type of correlation between the levels of interactions } \\
\text { based on certain criteria: the group size and the nature of labor based on a } \\
\text { comparative analysis of the obtained results }\end{array}$ & \\
\hline
\end{tabular}

Figure 2. Stages of regional economic structure development according to the evolutionary approach

The presented procedure for estimating the level of human resources' interactions consists of three stages (Figure 2). During the first stage, classification of information concerning activities and the number of participants is implemented in order to provide it to the expert as the head of the community or the unit. The second stage involves determining the coefficient $d_{i}$. During the third step, the coefficient of interactions $k_{j}$ for the communities members (large groups with a manual nature of labor) and the structural unit's team (small groups with intellectual labor) is calculated. The last stage of the procedure means conducting a comparative analysis of the obtained results in order to determine the nature of the level's dependence on the group size and the nature of labor. The importance of analyzing the level of interactions is determined by its meaning, both for the community with a large amount of human resources and for a small team.

Interactions play a key role in the functioning and development of united territorial communities, because: 
- the interactions result in achievements that are unattainable for one person because the potential of the team is much bigger than the sum of potentialities of each of its members;

- the sustainability of interactions during the time a territorial community exists. Thus, it becomes possible to have a joint influence on each other, which leads to the setting of common goals and interests, real awareness of this community and the integrity of factual actions.

Interactions of communities' human resources' contribute to the emergence of a synergetic effect. It is explained by obtaining an additional result from the close co-ordinated interactions of individual parts of a system.

The study focuses on interactions between human and labor resources because the proposed methodical approach considers time expenditures for participation in certain activities. As a rule, labor resources, due to a lack of time, do not actively participate in joint activities. Therefore, there is a scientific interest to calculate the coefficient of interactions for human and labor resources separately. The coefficient of interactions for communities and structural units are calculated in turn: first for communities, and then for structural units. Then, comparative analysis according to the distinguished criteria: the group size (large, small) and the nature of labor (manual, intellectual) are conducted. We consider the example of calculation of the coefficient of interactions for an ordinary united territorial communities. Data about community members' participation in its activities are shown in Table 2.

Analysis of the coefficient of interactions calculated for three communities proves that the community with the least amount of human resources 1130 people - has the highest value. The coefficient of interactions for this community is 1.28 for active participation of human resources in general and 1.12 for labor resources. That is, the interactions between human resources are determined by their total number and level of involvement in teamwork. It is commonly believed that the association of people with a small number of human resources has a higher level of interactions than large groups. Such a result is achieved by self-organization. The largest territorial community has the lowest coefficient of interactions in terms of human and labor resources -1.07 and 1.05, respectively, which can be explained by difficulties of large groups`organization, structuring and management. 
Table 2. Data of an «ordinary communities» to calculate the coefficient of interactions

\begin{tabular}{|c|c|c|c|c|c|c|}
\hline \multirow[t]{2}{*}{ Activities } & \multirow[t]{2}{*}{$d_{i}$} & $\begin{array}{l}\text { Number of } \\
\text { community } \\
\text { residents } \\
(H R) \text {, persons }\end{array}$ & \multicolumn{2}{|c|}{$\begin{array}{l}\text { Amount of human } \\
\text { resources, participated } \\
\text { in the event }\left(H R_{i}\right), \\
\text { persons }\end{array}$} & \multicolumn{2}{|c|}{$\begin{array}{l}\text { Number of employees who } \\
\text { participated in the event () } \\
\text { persons }\end{array}$} \\
\hline & & \multicolumn{5}{|c|}{ Ordinary community 1} \\
\hline Column 1 & Column 2 & Column 3 & $\begin{array}{l}\text { Column } 4 \\
\text { persons }\end{array}$ & share & $\begin{array}{l}\text { Column } 5 \\
\text { persons }\end{array}$ & share \\
\hline 1. Community day & 1 & 1250 & 560 & 0.448 & 410 & 0.328 \\
\hline $\begin{array}{l}\text { 2. Contest «The best } \\
\text { community» }\end{array}$ & -1 & - & - & - & - & - \\
\hline 3. Sport competitions & 0 & - & - & - & - & - \\
\hline 4. Joint projects & 1 & 1250 & 480 & 0.384 & 300 & 0.24 \\
\hline 5. Purity day & 1 & 1250 & 460 & 0.368 & 320 & 0.256 \\
\hline Geometric mean value & 0.4 & & & 0.399 & & 0.272 \\
\hline \multicolumn{7}{|c|}{ Ordinary community 2} \\
\hline Column 1 & Column 2 & Column 3 & $\begin{array}{l}\text { Column } 4 \\
\text { persons }\end{array}$ & share & $\begin{array}{l}\text { Column } 5 \\
\text { persons }\end{array}$ & share \\
\hline 1. Community day & 1 & 1420 & 670 & 0.472 & 530 & 0.373 \\
\hline $\begin{array}{l}\text { 2. Contest «The best } \\
\text { community» }\end{array}$ & 0 & - & - & - & - & - \\
\hline 3. Sport competitions & 1 & 1420 & 380 & 0.268 & 254 & 0.179 \\
\hline 4. Joint projects & -1 & - & - & - & - & - \\
\hline 5. Purity day & 0 & - & - & - & - & - \\
\hline Geometric mean value & 0.2 & & & 0.356 & & 0.258 \\
\hline \multicolumn{7}{|c|}{ Ordinary community 3} \\
\hline Column 1 & Column 2 & Column 3 & $\begin{array}{l}\text { Column } 4 \\
\text { persons }\end{array}$ & share & $\begin{array}{l}\text { Column } 5 \\
\text { persons }\end{array}$ & share \\
\hline 1. Community day & 1 & 1130 & 620 & 0.549 & 312 & 0.276 \\
\hline $\begin{array}{l}\text { 2. Contest «The best } \\
\text { community» }\end{array}$ & 0 & - & - & - & - & - \\
\hline 3. Sport competitions & 1 & 1130 & 540 & 0.478 & 180 & 0.159 \\
\hline 4. Joint projects & 0 & - & - & - & - & - \\
\hline 5. Purity day & 1 & 1130 & 420 & 0.372 & 220 & 0.195 \\
\hline Geometric mean value & 0.6 & & & 0.460 & & 0.205 \\
\hline
\end{tabular}

Calculation of the coefficient of interactions is shown in Table 3.

Table 3. Calculation of the coefficient of interactions by different methods

\begin{tabular}{llccc}
\hline Methods & \multicolumn{3}{c}{ Calculated meaning } & \\
\hline \multirow{2}{*}{ Column 1 } & \multicolumn{2}{c}{ Column 2 } & Column 3 & Column 4 \\
Adjusted $k_{j}$ & Human resources & Ordinary community 1 & Ordinary community 2 & Ordinary community 3 \\
& Working population & 1.16 & 1.07 & 1.28 \\
\hline
\end{tabular}

Within the framework of the proposed methodology, one can identify the "ideal" community in terms of interactions and provide comparative analysis of an ordinary community with the ideal one. The ideal is the community which applies all kinds of activities, and its members take part in all of them, so for all activities $=1$. To calculate the coefficient of interactions for the "ideal" community we use the following formulas: 


$$
\begin{gathered}
k_{j \text { ideal }} H R=1+\overline{Q_{H R_{l}}} \\
k_{\text {jideal }} L R=1+\overline{Q_{L R_{l}}}
\end{gathered}
$$

We calculate the coefficient of interactions using our example

$$
\begin{aligned}
& \text { 1) Ordinary community } 1 \quad \begin{array}{l}
k_{j \text { ideal }} H R=1+\overline{Q_{H R_{l}}}=1+0.399=1,399 \approx 1.40 \\
k_{j \text { ideal }} L R=1+\overline{Q_{L R_{l}}}=1+0.272=1,272 \approx 1.27
\end{array} \\
& \text { 2) Ordinary community } 2 \quad \begin{aligned}
k_{j \text { ideal }} H R & =1+\overline{Q_{H R_{l}}}=1+0.356=1,356 \approx 1.36 \\
k_{\text {jideal }} L R & =1+\overline{Q_{L R_{l}}}=1+0.258=1,258 \approx 1.26
\end{aligned} \\
& \text { 3) Ordinary community } 3 \begin{aligned}
k_{j \text { ideal }} H R & =1+\overline{Q_{H R_{l}}}=1+0.460=1,460 \approx 1.46 \\
k_{j \text { ideal }} L R & =1+\overline{Q_{L R_{l}}}=1+0.272=1,205 \approx 1.21
\end{aligned}
\end{aligned}
$$

According to the calculations of deviations from the ideal state presented in Table 4, the second community is the most distant one from the "ideal" characterized by the coefficient of human and labor resources" interactions -0.29 and 0.21 , respectively. The best results for team cohesion are demonstrated by the third team, which, as we noted above, has an insignificant number of human resources. In general the calculations of the coefficient of interactions presented in Table 4 clearly demonstrate that the level of human resources' cohesion is less than the interactions amongst employed community members, as the deviation between the coefficient of interactions when comparing the "ideal" and "ordinary community 1" for human resources is 0.18 , and for employed members -0.09 .

The reasons can be explained by the determinant of limited time resources. As a rule, people who are employed make decisions about participating in a particular event, selecting between the alternatives in favor of attending a certain event or vice versa. Mostly other alternatives are selected. The determined coefficient makes it possible to determine a set of measures that would contribute to the participation of community members in joint activities and the achievement of a common goal. 
The calculation results are shown in Table 4.

Table 4. Calculation of the coefficient of interactions according to different methodical approaches for an "ideal" and "ordinary" communities

Values

Coefficient of interactions Ordinary community 1 Ordinary community 2 Ordinary community 3

$k_{j} H R$ 1.16

1.07

1.05

1.36

1.26

0.29

0.21
1.11

1.40

1.27

0.16
1.28

1.12

1.46

1.21

0.18

0.09

Let us consider empirical implementation of the proposed approach using the example of a structural unit (university department), as a small group with an intellectual nature of labor. As we study labor resources, we calculate the coefficient of interactions using analytical dependencies for labor resources (formula 4-5). The head of the unit acts as an expert, who estimates the coefficient. Data on the participation of team members in the activities are presented in Table 5.

We determine the coefficient of interactions for a structural unit's team - ordinary and ideal meaning:

1) Unit 1:

2) Unit 2:

$$
\begin{gathered}
k_{\text {jideal }} H R=1+\overline{Q_{H R_{l}}}=1+0.786=1 . .786 \approx 1.79 \\
k_{j \text { ideal }} L R=1+\overline{Q_{L R_{l}}}=1+0.554=1.554 \approx 1.55
\end{gathered}
$$

3) Unit 3:

$$
\begin{aligned}
k_{\text {jideal }} H R & =1+\overline{Q_{H R_{l}}}=1+0.658=1.658 \approx 1.66 \\
k_{j \text { ideal }} L R & =1+\overline{Q_{L R_{l}}}=1+0.530=1.530=1.53
\end{aligned}
$$

$$
\begin{gathered}
k_{\text {jideal }} H R=1+\overline{Q_{H R_{l}}}=1+0.617=1.617 \approx 1.62 \\
k_{j \text { ideal }} L R=1+\overline{Q_{L R_{l}}}=1+0.541=1.541 \approx 1.54
\end{gathered}
$$


Table 5. Data on structural unit's team used to determine the coefficient of interactions

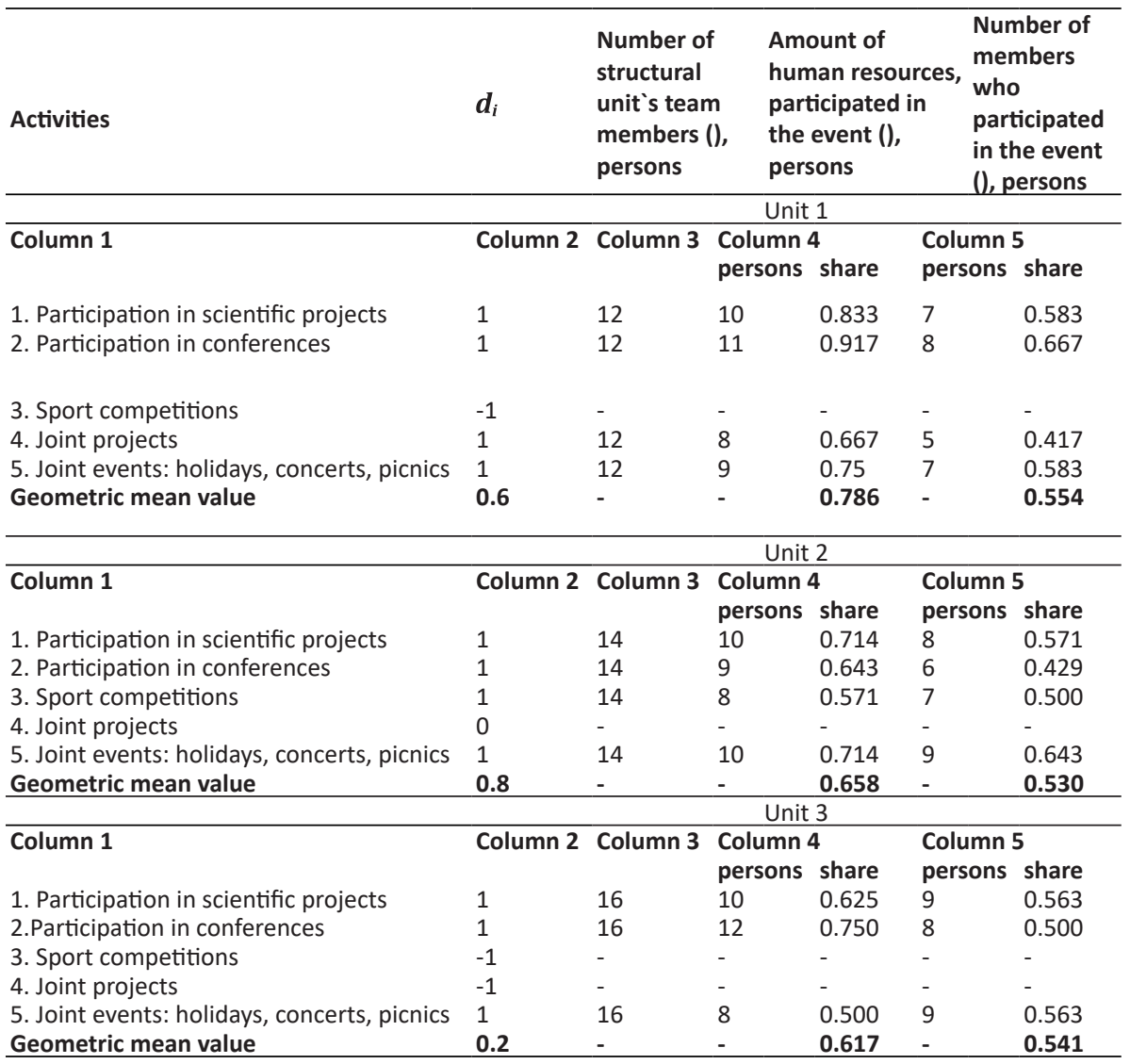

To conduct a comparative analysis, we use the determined criteria: the group size and the nature of labor and put the obtained results of calculations concerning community and structural units in Table 6 .

The comparisons of calculations of coefficient of interactions in communities and structural units obtained in Table 6 show that in the latter, this coefficient is higher. This can be attained by active participation in joint activities and the achievement of common goals. It should be noted that in spite of different nature of activities considered as a type of activity for attracting human resources determined by various fields of activity intellectual and predominantly manual labor, there is a relationship between the number of group members (small or large) and the nature of labor (intellectual or manual). 
Table 6. Comparative analysis of community`s and structural unit`s coefficient of interactions

\begin{tabular}{|c|c|c|c|c|c|c|}
\hline Value & \multirow{2}{*}{\multicolumn{3}{|c|}{ Column 2}} & \multicolumn{3}{|c|}{ Structural units } \\
\hline \multirow[t]{2}{*}{ Column 1} & & & & \multicolumn{3}{|c|}{ Column 3} \\
\hline & Community 1 & Community 2 & Community 3 & Unit 1 & Unit 2 & Unit 3 \\
\hline$k_{j} H R$ & 1.16 & 1.07 & 1.28 & 1.47 & 1.53 & 1.12 \\
\hline$k_{j \text { ideal }} H R$ & 1.40 & 1.36 & 1.46 & 1.79 & 1.66 & 1.62 \\
\hline$k_{j} L R$ & 1.11 & 1.05 & 1.12 & 1.33 & 1.42 & 1.11 \\
\hline$k_{\text {j ideal }} L R$ & 1.27 & 1.26 & 1.21 & 1.55 & 1.53 & 1.54 \\
\hline$k_{j}$ ideal $H R-k_{j} H R$ & 0.24 & 0.29 & 0.18 & 0.32 & 0.13 & 0.50 \\
\hline$k_{j \text { ideal }} L R-L R$ & 0.16 & 0.21 & 0.09 & 0.22 & 0.11 & 0.43 \\
\hline
\end{tabular}

It should also be emphasized that if the group is large, the level of interactions is lower than for a small group. The inverse dependence exists. A team with intellectual labor dominance has a greater level of interactions than that characterized by the domination of manual labor. This confirms the hypothesis $\mathrm{H} 1$ and $\mathrm{H} 2$. It should be noted that each team seeks to achieve the ideal state. It cannot be determined by the imitation of similar economic entities' functioning and development peculiarities, but is created on the basis of abilities, talents and moral qualities of human resources, and depends on the possibilities of coexistence within a certain environment, that is, the level of interactions as well.

A high level of human resources' interactions also affects performance. The indicator for a community and a structural unit is their ranking position compared to others. Thus, the higher the level of interactions, the greater the ranking position of an entity is. Of course, this also manifests itself in higher levels of income, profit, self-sufficiency-as material indicators; and recognition, self-realization - as intangible elements. That is, the level of human resources' interactions affects the activity performance (hypothesis $\mathrm{H} 3$ ).

\section{DISCUSSION}

The goal of the study was to propose a methodical approach to the assessment of human resources interactions. This approach is universal and can be used by different economic actors. We have used the approach for united territorial communities and structural unit.

Application of this approach allows us to state that human resources interactions depend on certain determinants. We considered two of them the group size and the nature of labor. The research showed that small groups 
with intellectual labor have a higher level of interactions than large groups with a predominance of manual labor. Nevertheless, the pattern is not typical for all business entities. It depends on a number of characteristics: activity type, age and gender structure of the human resources, and psychological characteristics. Therefore, the level of interactions in small groups is not always higher than in large ones, as is generally accepted.

The additional value of this study is represented by the following idea's justification: the level of interactions depends on the group size and the nature of labor. As commonly believed, a small group has a higher level of interactions and it is easier to manage. To a large extent, it also depends on other determinants and the ability of people to unite in order to achieve a common goal, and coexist in one environment. Implementation of the named approach allows us to state the fact that it is not a common pattern that small groups always have a relatively higher level of interactions. The level of interactions increases as the number of joint activities expands, so it depends on the community members' socially active lifestyle.

The main contribution of this study is the determination of the level of interactions between human resources which belong to different economic actors, e.g., to enterprises, of enterprises' units and united communities. Based on the obtained results, it is possible to work out specific measures that will increase the level of interactions and thereby create a positive synergetic effect. An additional advantage of this study is the substantiation of the conditional dependence of the interactions` level on the group size. It may seem that a small group of people has a higher level of interactions and it is easier to manage. However, to a large extent, this does not depend on the total number of group members, but on their active participation in joint activities and their ability to cooperate in order to achieve a common goal, to co-exist in one socio-economic system.

The importance of this research is also determined by the fact that it allows us to quantify the co-existence of people in one socio-economic environment, who are united not only by objective characteristics, but who also take into account subjective factors. Moreover, conforming to results, an economic entity (an enterprise, united communities) can redistribute financial expenditures and direct them to increase the level of cohesion and interactions of human resources in order to obtain a positive synergetic effect. In addition, measuring the "ideal" value of the coefficient of interactions, which is different for business entities, allows us to determine the level to be achieved. The fact that the "ideal" condition for different entities is unequal indicates the peculiarity and uniqueness of each business entity. That is, the "ideal" condition determines the existing potential, and the "ordinary" reveals the extent of its fulfillment. The greater the gap of the ordinary level 
of interactions from the "ideal" value, the less the level of the available human potential fulfillment is. Therefore, it makes sense not only to conduct a comparative analysis of the level of different entities ' human resources' interactions but also to determine the gap level of the real value from the ideal one, which allows us to conclude about the existing potential capabilities' fulfillment. This can be the basis for the formation of the "portfolio" tools and measures of human resources management. After all, people are the most complex "element" of the system in terms of management, as well as the most valuable, taking into account their importance for business effectiveness and obtaining the expected results from it. Assessment of the level of interactions allows us to come to the conclusion that the "energy potential" of the community is formed by the cumulative energy of each participant and combining it into a whole.

\section{CONCLUSION}

In our article, we proposed the methodical approach to assessing the level of human resources' interactions using the example of a united community and a structural unit. This made it possible to determine the dependence of the level of interactions on the group size (large or small) and the nature of labor (manual or intellectual). We found the impact of these criteria on the level of human resources 'interactions: for a community, which is a large group with the predominance of manual labor, the level of interactions is lower than for a structural unit, which is a small group with the domination of intellectual labor. A group is identified as large or small depending on the number of its members, comparing the number of people in a community and a structural unit. The nature of labor is determined by the peculiarities of community and unit activities. This is confirmed by our study, which includes calculations of the coefficient of a community's and a unit's human resources' interactions. Based on the obtained results we make the conclusion that the level of interactions depends on the group size and the nature of labor.

To determine a clear procedure for assessing the level of human resources' interactions process, we proposed an action plan that consists of four stages:

Stage 1 - classification of information concerning the activities list and the number of participants;

Stage 2 - determination of the coefficient based on expert assessment (community or department head act as the expert); 
Stage 3-calculation of the coefficient of interactions for a community's team (large group with a manual nature of labor) and a structural unit's team (small group with an intellectual nature of labor);

Stage 4-determination of the nature of the relationship between the level of interactions based on the criteria: the group size and the nature of labor on the basis of the comparative analysis results.

For empirical implementation of the proposed approach, particular analytical tools were used: expert assessment and analytical dependencies that allow one to calculate quantitatively the level of human resources' interactions for a community and a structural unit. A manager is assigned as an expert whose assessment is used to determine the coefficient that characterizes the presence or absence of certain activities and the activity participation. To determine the coefficient of interactions, certain mathematical dependencies are used. Comparative analysis of the level of human resources' interactions using the example of two entities, which are different in size and nature of labor, allowed us to distinguish their characteristic features, which are the basis for managerial decision-making.

The proposed methodical approach to the assessment of interactions of human resources allows us to make conclusions that are particularly important for economic actors 'functioning at all levels of the economy: from micro- to macro-level.

The calculated coefficient of interactions of the united territorial communities ' human and labor resources allows us to state that its meaning to a large extent depends not only on the physical participation in certain activities but also on the number of participants, that is, on the activity of community members. Strictly speaking, the more human resources are involved in community life, the greater the power of interactions between them and the community "strength."

The proposed approach is universal, as it can be used not only for communities but also for other business entities or their structural subdivisions.

It is important to determine the level of interactions, as it leads to the emergence of positive synergetic effect, which sets off a chain reaction and promotes the economic actors 'efficient functioning, and creates prospects for their further development. For the united territorial communities, it means an increase in their economic capacity, and growth of their own revenues' share in the community budget, and the achievement of absolute self-sufficiency in the future. For enterprises, it indicates improved performance and higher profits, and in the future access to new markets through the interactions of constituent elements. 
Making an "ideal" model to calculate the coefficient of interactions is a crucial advantage of the proposed approach. This allows scholars to assess development opportunities and the potential level of community growth. You can also determine the period needed to achieve the "ideal" state and manage these processes in real time: to accelerate or slow down movement to the "ideal" level according to the development level, influencing through the mechanisms of governance the level of human resources' interactions. The definition of an "ideal" value shows that the coefficient of interactions for the communities is less than the corresponding value of the "ideal" condition for structural units. That is, even though a structural unit has a greater coefficient of interactions, it is far behind the defined "ideal" condition in comparison with community.

For convenience, we summarize the results for the hypotheses below:

$\mathrm{H} 1$ : The relationship between the level of human resources 'interactions and the group size (co-workers, association of people), the nature of which may be determined by the ability to self-organization and management system 's features, is adopted;

$\mathrm{H} 2$ : The level of team interactions based on intellectual nature of labor, which is determined by the more active participation of human resources in group's activities, than in associations with the predominance of manual labor, is adopted;

H3: The level of interactions, which affects the results of the entity's business due to the positive effects of synergy, is adopted.

Our work is not without limitations. We offer only one approach that allows us to quantify the level of human resources 'interactions. The calculation of the coefficient of interactions is shown using the example of a community and a structural unit, using two criteria: the group size and the nature of labor. The level of interactions can be influenced by other determinants specified by the activity type, individuals distribution and age structure, gender, different psychological characteristics. The proposed approach has to be enhanced and improved when considering them. From a socio-psychological point of view, social and psychological orientations can play an important role in interactions, which allow one to identify certain group 's human resources' characteristics, determine its members' stereotypes, as well as predict their behavior in the future. Socio-psychological trends reflect the system, which directs the group and its members to certain norms of behavior: moral, 
social, economic and other. For example, within the socio-psychological trend called "process-result" one can conclude that the group members have a propensity to creative work and the process of its implementation, if the group predominantly focuses on the "process", and vice versa, if the focus is on the "result", it is mainly determined by the material parts. The socio-psychological trend "labor-money" is the indicator that determines the tangible or intangible part's domination in work motivation. It is interesting to determine the level of group interactions depending on the dominance of a particular motivation type. According to these features, groups may vary in terms of interactions. Definitely our task for further research is to find an effective approach for the precise, quantitative assessment of the level of human resources' interactions taking into account as many determinants as possible: material, social, psychological, as well as the development of a methodological approach that allows one to measure quantitatively the impact of the coefficient of interactions on an entity's performance. This will allow us to identify key aspects of human resources management policy. It is also useful for making managerial decisions. After all, there is a correlation between the performance (of enterprise, community, structural unit) and human resources' interactions. The quantitative assessment of this correlation will allow us to develop an effective mechanism of human resources management aimed at their preservation and development in the future. Due to a chain reaction, this will contribute to the achievement of high efficiency and performance effectiveness. Future work will grapple with some of these issues.

\section{Acknowledgments}

This research is performed in the framework of the state budget project. The state registration number 0117U0005101/17 «Formation, development of infrastructure and management technologies of communal property of Ukraine» (2017-2019), Zaporizhzhya National University

\section{References}

Banerjee, M., Tolbert, P., \& DiCiccio, T. (2012). Friend or foe? The effects of contingent employees on standard employees' work attitudes. International Journal of Human Resource Management, 23(11), 2180-2204.

Bingham, J., Oldroyd, J., Thompson, J., Bednar, J., \& Bunderson, J. (2014). Status and the true believer: The impact of psychological contracts on social status attributions of friendship and influence. Organization Science, 25(1), 73-92. 
Bridoux, F. Coeurderoy, R., \& Durand, R. (2017). Heterogeneous social motives and interactions: The three predictable paths of capability. Strategic Management Journal, 38(9), 1755-1773.

Brimhall, K., Mor Barak, M., Hurlburt, M., McArdle, J., Palinkas, L., \& Henwood, B. (2017). Increasing workplace inclusion: The promise of leader-member exchange. Human Service Organizations Management, Leadership and Governance, 41(3), 222-239.

Call, M., \& Nyberg, A. (2015). Stargazing: An integrative conceptual review, theoretical reconciliation, and extension for star employee research. Journal of Applied Psychology, 100(3), 623-640.

Chen, J., \& Garg, P. (2018). Dancing with the stars: Benefits of a star employee's temporary absence for organizational performance. Strategic Management Journal, 39(5), 1239-1267.

Cohen, M., Levinthal, D., \& Warglien, M. (2014). Collective performance: Modeling the interaction of habit-based actions. Industrial and Corporate Change, 23(2), 329-360.

Cumberland, D., Alagaraja, M., Shuck, B., \& Kerrick, S. (2018). Organizational social capital: Ties between HRD, employee voice, and CEOs. Human Resources Development Review, 17(2), 199-221.

Delmas, M., \& Pekovic, S. (2018). Corporate sustainable innovation and employee behavior. Journal of Business Ethnics, 150(4), 1071-1088.

Dibble, R., \& Gibson, C. (2018). Crossing team boundaries: A theoretical model of team boundary permeability and a discussion of why it matters. Human Relations, 71(7), 925-950.

Drach-Zahavy, A., \& Somech, A. (2010). From an intrateam to an interteam perspective of effectiveness: The role of interdependence and boundary activities. Small Group Research, 41(2), 143-174.

Edmondson, A., \& Nembhard, I. (2009). Product development and learning in project teams: The challenges are the benefits. Journal of Product Innovation Management, 26(2), 123-138.

Ethiraj, S., \& Garg, P. (2012). The division of gains from complementarities in human-capital-intensive activity. Organization Science, 23(3), 725-742.

Fang, C., Lee, J., \& Schilling, M. (2010). Balancing exploration and exploitation through structural design: The isolation of subgroups and organizational learning. Organization Science, 21(3), 625-642.

Faraj, S. \& Yan, A. (2009). Boundary Work in Knowledge Teams. Journal of Applied Psychology, 94 (3), 604-617.

Faraj, S., \& Yan, A. (2009). Boundary work in knowledge teams. Journal of Applied Psychology, 94(3), 604-617.

Gaisina, L., Belonozhko, M., Kirichuk, S., Sultanova, E., \& Tumanova, A. (2017). Self-organization and self-development as key factors in improving productivity. Journal of Advanced Research in Law and Economics, 8(2), 444-453. 
Gibson, C., \& Dibble, R. (2013). Excess may do harm: Investigating the effect of team external environment on external activities in teams. Organization Science, 24(3), 697-715.

Gibson, C., Cooper, C., \& Conger, J. (2009). Do you see what we see? The complex effects of perceptual distance between leaders and teams. Journal of Applied Psychology, 94(1), 62-76.

Glaz, V., Glaz, Y., \& Rusetskaya, E. (2017). The Improvement of labor activity motivation of workers in the process of their socialization in the organization: The influence of organizational culture. Journal of History Culture and Art Research, 6(6), 244-254.

Gonchar, O. (2008). The essence of "pedagogical interactions" definition in scientific and pedagogic science of Ukraine. Theory and Methodology of Training and Upbringing, 22, 32-38.

Gornostai, P.P. (2015). Group interaction in the psychological paradigms. Scientific Studies in Social and Political Psychology, 35, 113-126.

Grigoriou, K., \& Rothaermel, F. (2014). Structural microfoundations of innovation: The role of relational stars. Journal of Management, 40(2), 586-615.

Helfat, C., \& Martin, J. (2015). Dynamic managerial capabilities: Review and assessment of managerial impact on strategic change. Journal of Management, 41(5), 1281-1312.

Helfat, C., \& Peteraf, M. (2015). Managerial cognitive capabilities and the microfoundations of dynamic capabilities. Strategic Management Journal, 36(6), 831-850.

Hirst, G., \& van Dick, R. (2009). A social identity perspective on leadership and employee creativity. Journal of Organizational Behavior, 30(7), 963-982.

Hirst, G., Van Knippenberg, Zhou, J. (2009). A cross-level perspective on employee creativity: Goal orientation, team learning behavior, and individual creativity. Academy of Management Journal, 52(2), 280-293.

Hogg, M., \& Van Knippenberg, D. (2012). Intergroup leadership in organizations: Leading across group and organizational boundaries. Academy of Management Review, 37(2), 232-255.

Huang, L., Gibson, C., Kirkman, B., \& Shapiro, D. (2017). When is traditionalism an asset and when is it a liability for team innovation? A two-study empirical examination. Journal of International Business Studies, 48(6), 693-715.

Huckman, R., Staats, B., \& Upton, D. (2009). Team familiarity, role experience, and performance: Evidence from Indian software services. Management Science, 55(1), 85-100.

Hülsheger, U., Anderson, N., \& Salgado, J. (2009). Team-level predictors of innovation at work: A comprehensive meta-analysis spanning three decades of research. Journal of Applied Psychology, 94(5), 1128-1145.

Kearney, E., \& Gebert, D. (2009). Managing diversity and enhancing team outcomes: The promise of transformational leadership. Journal of Applied Psychology, 94(1), 77-89. 
Keizer, P. (2017). A multidisciplinary-economic framework of analysis. Journal of Philosophical Economics, 11(1), 103-132.

Kostopoulos, K., Spanos, Y., \& Prastacos, G. (2013). Structure and function of team learning emergence: A multilevel empirical validation. Journal of Management, 39(6), 1430-1461.

Leonardelli, G., Pickett, C., \& Brewer, M. (2010). Optimal distinctiveness theory. A framework for social identity, social cognition, and intergroup relations. Advances in Experimental Social Psychology, 43(C), 63-113.

Liborius, P. (2017). What does leaders' character add to transformational leadership? Journal of Psychology: Interdisciplinary and Applied, 151(3), 299-320.

Lin, C.H.V, \& Sun, J.M.J. (2018). Chinese employees' leadership preferences and the relationship with power distance orientation and core selfevaluation. Frontiers of Business Research in China, 12 (1), UNSP 6. http://doi.org//10.1186/s11782-018-0027-9

Litchfield, R., Karakitapoğlu-Aygün, Z., Gumusluoglu, L., Carter, M., \& Hirst, G. (2018). When team identity helps innovation and when it hurts: Team identity and its relationship to team and cross-team innovative behavior. Journal of Product Innovation Management, 35(3), 350-366.

Lopez, D. (2018). Dominant discourse by the leadership: negative reinforcement of human relationships. Innovar-revista de Ciencias Administrativas y Sociales, 20(36), 67-78.

Martin, J. (2011). Dynamic managerial capabilities and the multibusiness team: The role of episodic teams in executive leadership groups. Organization Science, 22(1), 118-140.

Melnikov, V. (2014). Synergetic effect in modeling innovative processes. Innovation Technologies and Economic Security, 5(54), 335-340.

Mitchell, R., Parker, V., \& Giles, M. (2011). When do interprofessional teams succeed? Investigating the moderating roles of team and professional identity in interprofessional effectiveness. Human Relations, 64(10), 1321-1343.

Morozov, V.A. (2015). The interaction: concept, types and features. Creative Economics, 9(10), 1309-1318.

Morrison, E. (2011). Employee voice behavior: Integration and directions for future research. Academy of Management Annals, 5(1), 373-412.

Mortensen, M. (2014). Constructing the team: The antecedents and effects of membership model divergence. Organization Science, 25(3), 909-931.

Okoe, A., \& Boateng, H. (2018). Examining human resource practice outcomes and service innovation. Service Industries Journal, 38(7-8), 431-445.

Pooja, A., De Clercq, D., \& Belausteguigoitia, I. (2016). Job Stressors and Organizational Citizenship behavior: The roles of organizational commitment and social interaction. Human Resource Development Quarterly, 27(3), 373-405. 
Rink, F., Kane, A., \& Ellemers, N. (2013). Team receptivity to newcomers: Five decades of evidence and future research themes. Academy of Management Annals, 7(1), 247-293.

Rousseau, V., \& Aubé, C. (2010). Team self-managing behaviors and team effectiveness: The moderating effect of task routineness. Group and Organization Management, 35(6), 751-781.

Russell, Z., Steffensen, D., Ellen, B., Zhang, L., Bishoff, J., \& Ferris, G. (2018). High performance work practice implementation and employee impressions of line manager leadership. Human Resource Management Review, 28(3), 258-270.

Salvato, C., \& Vassolo, R. (2018). The sources of dynamism in dynamic capabilities. Strategic Management Journal, 39(6), 1728-1752.

Schippers, M., West, M., \& Dawson, J. (2015). Team reflexivity and innovation: The moderating role of team context. Journal of Management, 41(3), 769-788.

Schneider, B., \& Bartram, D. (2017). Aggregate personality and organizational competitive advantage. Journal of Occupational and Organizational Psychology, 90(4), 461-480.

Somech, A., \& Khalaili, A. (2014). Team boundary activity: Its mediating role in the relationship between structural conditions and team innovation. Group and Organization Management, 39(3), 274-299.

Somech, A., Desivilya, H., \& Lidogoster, H. (2009). Team conflict management and team effectiveness: The effects of task interdependence and team identification. Journal of Organizational Behavior, 30(3), 359-378.

Starostina, A., \& Kravchenko, V. (2011). The essence and practical significance of applying the methodology of constructing a categorical apparatus of economic science (for example, the concepts of "globalization" and "entrepreneurial risk." Bulletin of Kiev University named after Shevchenko. Economics, 128, 5-10.

Tempest, S. (2009). Learning from the alien: Knowledge relationships with temporary workers in network contexts. International Journal of Human Resource Management, 20(4), 912-927.

Teoh, K., Coyne, I., Devonish, D., Leather, P., \& Zarola, A. (2017). The interaction between supportive and unsupportive manager behaviors on employee work attitudes. Personnel Review, 45(6), 1386-1402.

Tse, H., To, M., \& Chiu, W. (2018) When and why does transformational leadership influence employee creativity? The roles of personal control and creative personality. Human Resource Management, 57(1), 145-157.

Van der Vegt, G., Bunderson, S., \& Kuipers, B. (2010). Why turnover matters in self-managing work teams: Learning, social integration, and task flexibility. Journal of Management, 36(5), 1168-1191.

Wijewardena, N., Härtel, C., \& Samaratunge, R. (2017). Using humor and boosting emotions: An affect-based study of managerial humor, employees' emotions and psychological capital. Human Relations, 70(11), 1316-1341. 
Wilkin, C., de Jong, J., \& Rubino, C. (2018). Teaming up with temps: the impact of temporary workers on team social networks and effectiveness. European Journal of Work and Organizational Psychology, 27(2), 204-218.

Zanozovska, O. (2017). The effects of the quality of employees' interactions with their managers on their work. Baltic Journal of Economics Studies, 3(2), 33-42.

\begin{abstract}
Abstrakt
Zgodnie z naszq wiedzq istnieje potrzeba opracowania metodologicznego podejścia do oceny poziomu interakcji między społecznościami w ramach zasobów ludzkich, jako dużej grupy, a także oddzielnej jednostki strukturalnej - małej grupy. To pozwala nam określić zależność poziomu interakcji od liczby osób, które wchodzq w interakcje w ramach danej struktury i charakteru wykonywanej przez nich działalności - pracy intelektualnej lub fizycznej. Celem naszych badań jest wypracowanie podejścia metodologicznego do oceny poziomu interakcji zasobów ludzkich, co pozwala nam zidentyfikować kluczowe obszary i środki polityki. Ekspertyzy i zależności analityczne sq używane jako narzędzia badawcze w artykule. Narzędzia te pozwalajq nam ilościowo określić poziom interakcji zasobów ludzkich dla pojedynczej jednostki. Empiryczna implementacja proponowanego podejścia, na przykładzie dwóch podmiotów o różnym rozmiarze i charakterze pracy, pozwoliła nam dokonać analizy porównawczej i wyróżnić cechy charakterystyczne, które sq podstawq do podejmowania decyzji zarzqdczych. Menedżer działa jako ekspert, który ocenia obecność lub nieobecność określonego zdarzenia w podległej jednostce. Wskaźnik, który charakteryzuje obecność lub brak określonych działań i poziom uczestnictwa w nich, określa się na podstawie oceny menedżerskiej. Kolejnym etapem jest określenie współczynnika interakcji za pomoca pewnych zależności matematycznych i analizy wyników. W wyniku przeprowadzonych badań uzyskaliśmy ocenę poziomu interakcji zasobów ludzkich między dwoma podmiotami - zjednoczonq społecznościq i jednostkq strukturalnq. Ocena wykazała zależność od poziomu interakcji i wielkości podmiotu (małe i duże grupy) oraz charakteru pracy. Wyniki pokazały, że jednostka strukturalna, skoncentrowana na pracy intelektualnej i prezentowana przez mała grupę, ma wyższy poziom interakcji niż zjednoczona społeczność, która ma większy rozmiar i przewagę pracy fizycznej.
\end{abstract} Słowa kluczowe: ocena, zasoby ludzkie, interakcje, praca, efekt synergiczny.

\title{
Biographical note
}

Anna Pereverzieva - Ph.D. in Economics, associate professor of International economics, natural resources and economic theory department, Zaporizhzhya National University. Since 2007, she has been working on scientific topics dedicated to human resources and the improvement of management methods within united territorial communities. Her scientific interests include the knowledge economy, human capital, human resources, and the development of united territorial communities. She has authored more than 50 scientific works, including 30 in scientific journals. 
